\title{
Geçici Anormal Miyelopoezis Gelişen Mozaik Down Sendromlu Yenidoğan Olgusu
}

\section{Transient Abnormal Myelopoiesis in a Newborn with Mosaic Down Sydrome}

\author{
Ali Ulaş TUĞCU¹, Burcu BELEN APAK², Deniz ANUK INCE¹, Özden TURAN, Lale OLCAY², Ayşe ECEViT¹
}

\author{
'Başkent üniversitesi, Tıp Fakültesi, Ankara Hastanesi, Çocuk Sağlığı ve Hastalıkları Anabilim Dalı, Yenidoğan Bilim Dalı, \\ Ankara,Türkiye \\ ${ }^{2}$ Başkent üniversitesi, Tıp Fakültesi, Ankara Hastanesi, Çocuk Sağlığı ve Hastalıkları anabilim Dalı, Çocuk Hematoloji Bilim Dalı, \\ Ankara,Türkiye
}

\begin{abstract}
Öz
Down Sendromlu (DS; trizomi 21) infantlar, yenidoğan döneminde Transient Anormal Miyelopoez (TAM) olarak da bilinen, geçici myeloproliferatif hastalık gelişimi açısından risk altındadır. Transient Anormal Miyelopoez, DS klasik belirteçlerine sahip olan hastalarda görülebildiği gibi, Down Sendromu klasik belirteçlerine sahip olmayan mozaisizm gösteren hastalarda da ortaya çıkabilir. DS'lu yenidoğanların \%4- 10'unda TAM gelişmektedir. TAM'ı bebeklerin çoğu remisyona girer ve herhangi bir tedavi gerekmez. Bu sunumda, kusma ve kanlı dışklama şikayeti ile başvuran ve ileri değerlendirmeler sonucu; Mozaik Down Sendromu ve TAM tanıları konan yenidoğan olgusuna dikkat çekmek amaçlanmışıı.
\end{abstract}

Anahtar Sözcükler: Mozaik Down Sendromu, Remisyon, Transient Anormal Miyelopoez

\begin{abstract}
Infants with Down Syndrome (DS; trisomy 18) are under the risk for development of Transient Abnormal Myelopoiesis (TAM) during newborn period. TAM is mostly seen in classical form of DS but also might be seen in infants with mosaic type of DS. 4-10 \% of infants with DS develop TAM. Most of infants with TAM, do not need any treatment and go into remission. Here, we tried to arouse interest on a newborn who has been consulted with compaints of vomiting and bloody stool and diagnosed as DownSyndrome with TAM.
\end{abstract}

Key Words: Mosaic Down Sydrome, Remission, Transient Abnormal Myelopoiesis

\section{GiRiş}

Down Sendromlu (DS; trizomi 21) infantlar yenidoğan döneminde Transient Anormal Miyelopoez (TAM) olarak da bilinen, geçici myeloproliferatif hastalık gelişimi açısından risk altındadır. Transient Anormal Miyelopoez, DS klasik belirteçlerine sahip olan hastalarda görülebildiği gibi, Down Sendromu klasik belirteçlerine sahip olmayan mozaisizm gösteren hastalarda da ortaya çıkabilir. DS'luyenidoğanların \%4-10'unda TAM gelișebildiği bilinmektedir (1). Etiyolojide, öncelikli olarak; fetal karaciğerde hematopoezin trizomi 21'e bağlı olarak bozulması, GATA-1 mutasyonları ve hematopoetik mikro çevre rol oynamaktadır. Son dönemde IGF (insülin like growth faktör) sinyal yolağındaki bozukluğun da, TAM gelișimine neden olabildiği gösterilmiștir (2). TAM'lı bebeklerin çoğu remisyona girer ve herhangi bir tedavi gerekmez. Hepatik, renal, kardiyak ve akciğer tutulumu olan olgularda ise, kısa süreli düșük doz sitozin arabinozid tedavisi önerilmektedir.
Bu sunumda, kusma ve kanlı dışkılama şikayeti ile çocuk acile başvuran ve ileri değerlendirmeler sonucu; Mozaik Down Sendromu ve TAM taniları konan yenidoğan olgusunu sunmak istedik.

\section{OLGU}

28 yaşındaki annenin 4. gebeliğinden 2.yaşayan, 38 haftalık, 3100 gr olarak normal spontan vajinal yol (NSVY) ile doğan bebek (1. dakika Apgar skoru 9,5. dakika Apgar skoru: 10) postnatal 21. gününde kanlı gayta, kusma ve huzursuzluk şikayeti ile hastanemize başvurdu. Fizik incelemesinde, anal fissür ile birlikte, tek elde simian çizgisi (+) dışında patolojisi saptanmadı (Resim 1).

Tam kan sayımında; Hb: $15.8 \mathrm{gr} / \mathrm{dl}$, trombosit: 236.000/mm³, beyaz küre: 54000/mm³, Laktat Dehidrogenaz LDH : 1500 


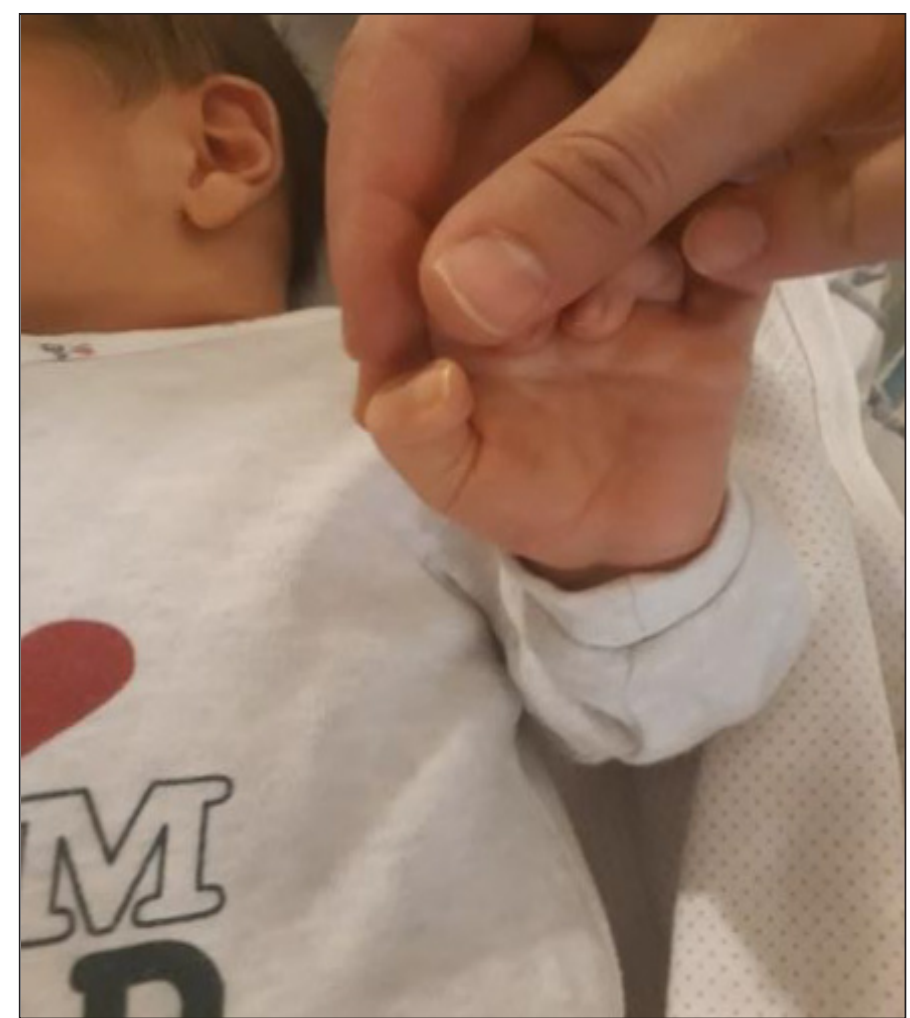

Resim 1: Sol elde simian çizgisi

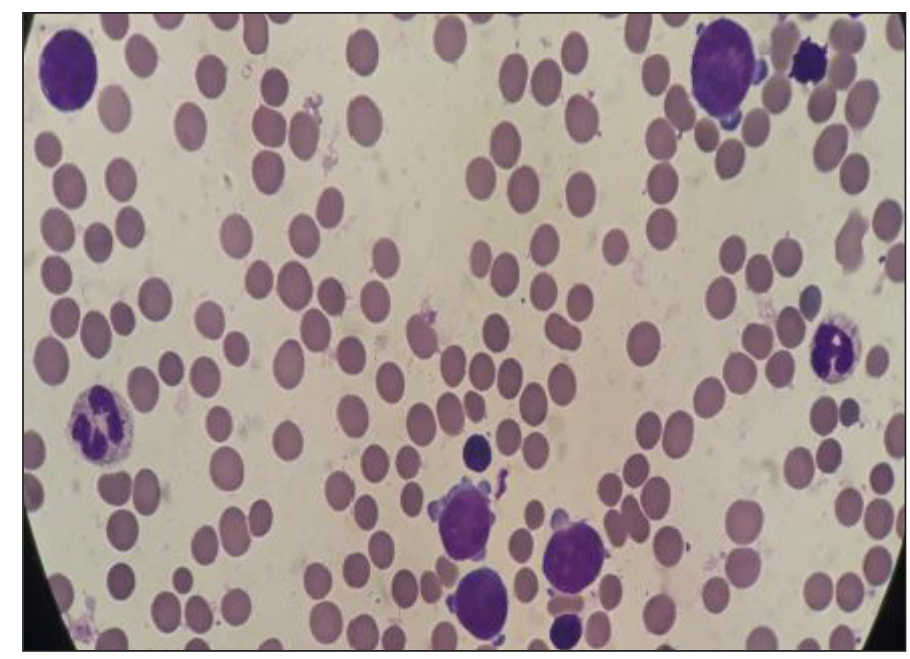

Resim 3: Kemik iliğinde blastlar

U/l, Fosfor (P): $6.5 \mathrm{mg} / \mathrm{dl}$ ve Potasyum (K): $6.5 \mathrm{mg} / \mathrm{dl}$ olarak saptandı. TORCH (Toksoplazma, Rubella, CMV, Herpes Simplex Virus) serolojisi negatifti. Direk Coombs (-), retikülosit sayısı \% 0.5'di. Hastanın periferik yaymasında \% 61.5 oranında blast görüldü (Resim 2). Kemik iliği değerlendirmesinde, \%33 oranında, büyük bizzare nükleusları olan ve sitoplazmaları bleb yapmış blastlar saptandı (Resim 3).

Hastanın karyotip analizi yapıldı, FISH tekniği ile yanak mukozasından alınan somatik hücrelerde, 21. kromozoma ait \% 3 trizomi saptandı. Immünfenotipik değerlendirmesi (CD19:

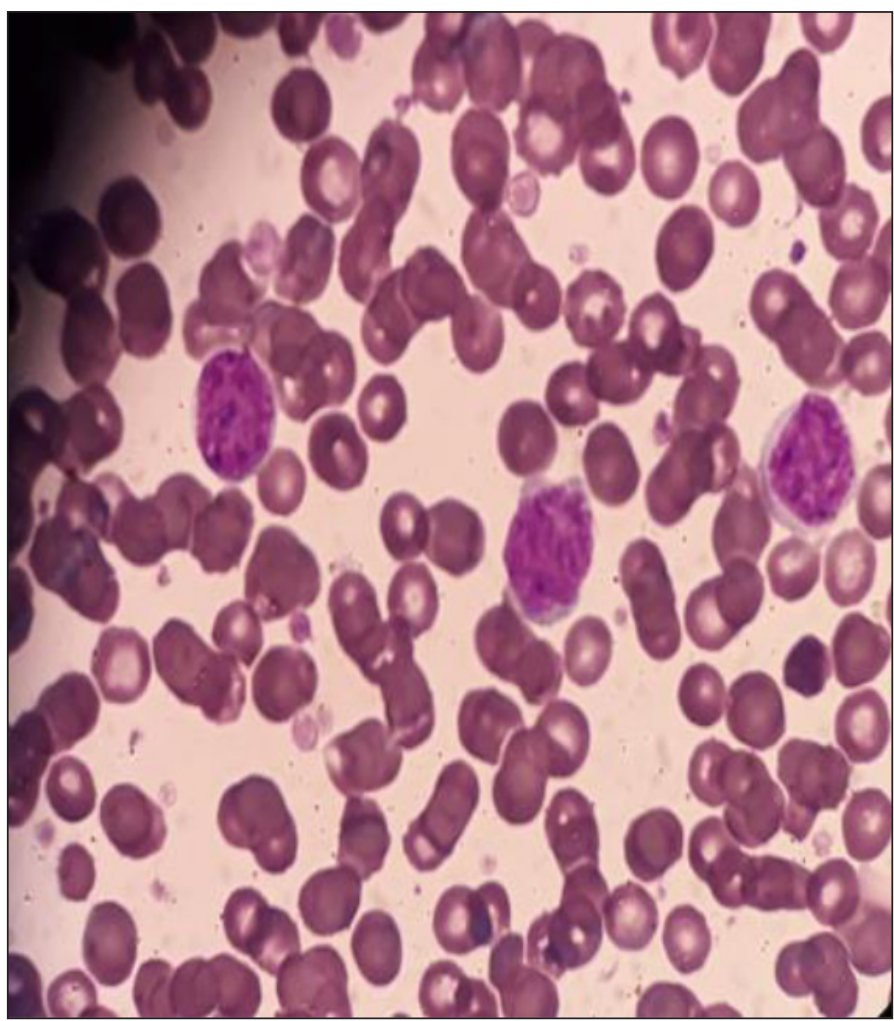

Resim 2: Periferik blastlar

\% 0.3, CD7: \% 61, CD13: \% 0.2, CD64: \% 0.6, CD33: \% 52.7, CD34: \% 86, CD14: \% 0.6, CD11b: \% 0.5, CD45: \% 90, CD15: \% 0.2, CD117: \% 78, CD41a: \% 55.9, CD61: \% 63.2, HLA DRÇ: \%3.1), AML M7 ile uyumlu saptandı. Hastanın GATA-1 mutasyonu pozitifti. Yatış süresince, düzenli olarak tam kan sayımı takibi yapılan hastanın beyaz küre sayısı, yatışının 3.gününde $23.670 / \mathrm{mm}^{3}$ 'e, 8 .gününde $17.480 / \mathrm{mm}^{3}$ 'e geriledi.

Hastanın periferik blast oranının \% 61, kemik iliği blast oranının \% 33 olması, beyaz küre seyrinin düşüş trendinde olması, blast morfolojisinin M7 ile uyumlu olması, blastik ve somatik hücreler birlikte karyotip ve FISH analiz sonucu değerlendirildiğinde; hastaya Down Sendromu (Mozaik) ve TAM tanıları kondu. Beyaz küre sayımının düşme eğiliminde olması, hepatosplenomegali ve organ tutulumu olmaması ve solunum sıkıntısının olmaması nedeniyle tedavi verilmedi. Yatıșının 8. gününde taburcu edilen hastanın ayakta ve remisyonda izlemi sürmektedir.

\section{TARTIŞMA}

Transient Anormal Miyelopoez, çoğunlukla DS'lu olgularda görülür. Yenidoğanlarda \% 4-10 arasında rastlanır $(1,3)$. Çocuklarda tam insidansı bilinmemektedir. Yenidoğan döneminde tespit edildiği günler, ortanca: 3-7 gündür. Oxford Imperial Down Syndrome Cohort Study, TAM tanısı için \% 10'dan fazla blast ile birlikte GATA-1 mutasyon pozitifliğinin gerektiğini belirtmiștir (4). Hastamızda, GATA-1 pozitifliğinin yanı 
sıra, periferik yayma değerlendirmesinde \% 61 blast saptanması ile TAM tanısı konulmuştur.

Hastalarda en sık görülen şikayet ve semptomlar, hepatomegali (\% 60), splenomegali (\% 35-40), sarllk (\%15), perikardiyal ve/veya plevraleffüzyon (\%10-15), asit (\% 10), solunum distresi (\%10), kanama (\% 10)'dır. Hastaların \% 10-25'i nonsemptomatiktir. Hastamızın başvuru tanısı kanlı dışkılamaydı, bu şikayetinin anal fissüre bağlı olarak geliștiği düşünüldü.

Laboratuvar bulguları olarak en sık lökositoz (Vakaların \%20 -30'unda 100 000/mm³ ve üstü), trombositopeni (\%40) ve periferik dolaşımda artmış blastlar saptanır. Hastamızın başvuru değerleri literatür ile uyumluydu.

Hastaların \%80'i, 3 ay içinde spontanremisyona girerken; \% 20'sinde, 4 yll içinde Akut Megakaryoblastik Lösemi (AMKL) gelişir. Hastaların çoğu, tedavisiz olarak izlenir. Hastamız, kısa sürede remisyona girdi, tedavi endikasyonu gelişmedi.

Sonuç olarak, Down Sendromu olgularında TAM gelişebileceği akılda tutulmalıdır. Hastamızda da remisyon dönemi öncesinde tanı konulması ileri dönem izlemi açısından önem taşımaktadır. Bu olgularını çoğu, herhangi bir tedavi gereksinimi olmayan ve kendiliğinden remisyona giren olgular olsa da, bir kısmında ilerleyen yıllarda AMKL gelișebileceği akılda tutulmalıdır.

\section{KAYNAK}

1. Massey GV. Transient leukemia in newborns with Down syndrome. Pediatr Blood Cancer 2005; 44:29-32.

2. Klusmann JH, Godinho FJ, Heitmann K, Maroz A, Koch ML, Reinhardt D, et al. Developmental stage specific interplay of GATA1 and IGF signaling in fetal megakaryopoiesis and leukemogenesis. Genes Dev 2010;24:1659-72.

3. Massey GV, Zipursky A, Chang MN, Doyle JJ, Nasim S, Taub JW, et al. A prospective study of the natural history of transient leukemia $(T L)$ in neonates with Down syndrome (DS): Children's Oncology Group (COG) study POG-9481. Blood 2006; 107: 4606-13.

4. Roberts I, Alford K, Hall G, Juban G, Richmond H, Norton A, et al. GATA1-mutant clones are frequent and often unsuspected in babies with Down syndrome: identification of a population at risk of leukemia. Blood 2013; 122: 3908-17. 